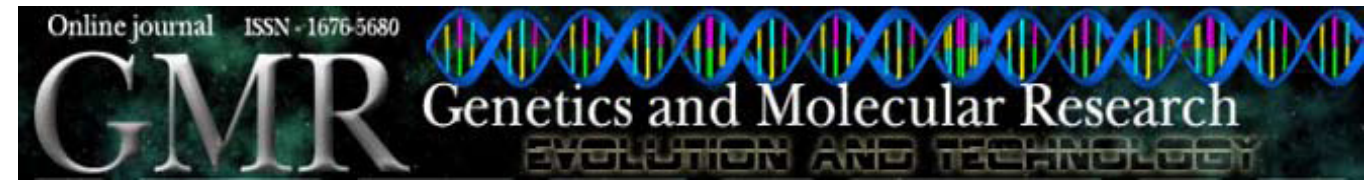

\title{
Increasing mutagenicity of São Gonçalo Channel waters based on the Allium cepa test
}

\author{
T.S. Paiva, G.L. Garcias and M.G. Martino-Roth \\ Laboratório de Genética, Escola de Saúde, Universidade Católica de Pelotas, \\ Pelotas, RS, Brasil \\ Corresponding author: T.S. Paiva \\ E-mail: thais.simoes.bio@hotmail.com
}

Genet. Mol. Res. 8 (1): 299-309 (2008)

Received September 8, 2008

Accepted November 8, 2008

Published March 17, 2009

\begin{abstract}
The São Gonçalo Channel is of great importance to the conservation of local biodiversity; it also is a water supply source of the city of Pelotas, Brazil, and the surrounding region. We examined the mutagenic activity of its waters. The following items were seasonally investigated in Allium cepa root radicular meristem cells: mitotic index, mitotic anomalies, interphase anomalies, and total anomalies. Water samples were collected from four different stations, Lock Dam, Santa Bárbara Channel, Pelotas Creek, and Barra do Laranjal. A drinking water negative control was used. For each sampling station, 8000 cells were counted, 2000 of which by repetition. The data were computed on a database (SPSS), and then analyzed by the chi-square test and the Mann-Whitney U-test. In 2005, the channel water provoked a significantly greater number of anomalies than the control water. The number of anomalies increased in 2007. This suggests that there was an increase in toxic substances in the channel over the years.
\end{abstract}

Key words: Allium cepa; Anomalies; Channel; Meristems; Mutagenicity 


\section{INTRODUCTION}

Water - an indispensable resource for the survival of every species - exerts a decisive influence upon the quality of life of populations (Ferreira and Cunha, 2005). Fresh water environments are used for distinct aims, among which are water supply, energy generation, irrigation, navigation, aquiculture, and landscape harmonization (Moraes and Jordão, 2002).

The population increase and the accelerated advancement in industrialization and urbanization processes in society (McMichael, 2000), along with distinct ways of water resource use and management, have led to a high degree of environmental degradation and risk of water shortage, which have compromised the quality of life for future generations (Moraes and Jordão, 2002).

Fresh water habitats, which cover a small portion of the planet's surface, are vitally important for mankind, as they constitute an appropriate, low-cost source for fulfilling their needs. However, such habitats often become effluent discharge systems for nearby cities (McMichael, 2000).

São Gonçalo Channel provides a link between Mirim Lagoon and Patos Lagoon, running SW-NE with an extension of $62 \mathrm{~km}$. Its width ranges from 200 to $300 \mathrm{~m}$, and its average depth is $6 \mathrm{~m}$. Its waters are influenced by both lagoons, and may flow both ways, depending on the level difference between the lagoons and on wind action. Its main affluent is the Piratini River (Ministério dos Transportes, 2001).

The study of São Gonçalo Channel waters is important due to the importance of such water resource for the communities in the southern region of Rio Grande do Sul State, as the ecosystem is designed to be the water supply source for the city of Pelotas. Nowadays, it is already being used for supplying water to the city of Rio Grande. Also, there is the biodiversity issue, as the channel connects two environments of inestimable biological importance, Mirim Lagoon and Patos Lagoon (Capitoli and Bemvenuti, 2005).

Biological toxicity and genotoxicity tests are key to characterize the quality of a water resource (Alba-Tercedor, 1994), assess the responses of living organisms to complex environmental pollution, and demonstrate the potential synergistic effects of several pollutants, whereas physicochemical analyses identify the presence and respective levels of several pollutants; that is, they only reflect the sampling moment (Moraes et al., 2002).

Mutagenicity tests aim at detecting and understanding the action of certain substances called genotoxins on organisms, with specificity for nucleic acids, particularly DNA (Pereira et al., 2002).

Allium cepa is a biological material of great importance for mutagenicity tests, due to the simplicity of its use in testing, the fast growth of its roots, and the response of the genetic material to the presence of substances with cytotoxic and genotoxic potential (Smaka-Kincl et al., 1996; Evandri et al., 2000). The test is routinely used around the world, at laboratories working with toxicological genetics. It provides the assessment of the degree of pollution of environments and of the toxicity caused by industrial, agricultural and domestic effluents, by determining the reduction in the mitotic index (MI) and the formation of chromosomal aberrations (Fiskejö, 1993).

Therefore, through the determination of the mutagenic level, by investigating the MI, mitotic anomalies (MA), interphase anomalies (IA), and total anomalies (TA) in root meristem cells of A. cepa, the aim of the present research was to study and assess São Gonçalo Channel 
waters, thereby contributing to the scarce studies on such an important channel in the southern region of Brazil.

\section{MATERIAL AND METHODS}

Two tests were conducted in order to study and assess the waters in São Gonçalo Channel. The first one was an in vivo test (A. cepa test), the other was through a physicochemical analysis of water collected from the channel, both carried out at the Universidade Católica de Pelotas (UCPel) at the Genetics Laboratory of the Health School and the Environmental Chemistry Laboratory of the Environmental Sciences School, respectively.

\section{Sampling}

Four sampling stations were chosen along the São Gonçalo Channel (Figure 1), where water samples were collected seasonally during the years 2005 and 2007. The sampling stations (Figure 1) are identified as follows: Point 1, situated by the Lock Dam, at the Mirim Lagoon Agency in the city of Capão do Leão; Point 2, situated in the Santa Bárbara Channel, near São Gonçalo Channel bridge; Point 3, situated in Pelotas Creek, near a rice-processing plant, and Point 4, in Barra do Laranjal, by the mouth of São Gonçalo Channel at Patos Lagoon. Water samples were collected by the bank at each point and stored in labeled 2-liter PET bottles for both the physicochemical analyses and the $A$. cepa tests.

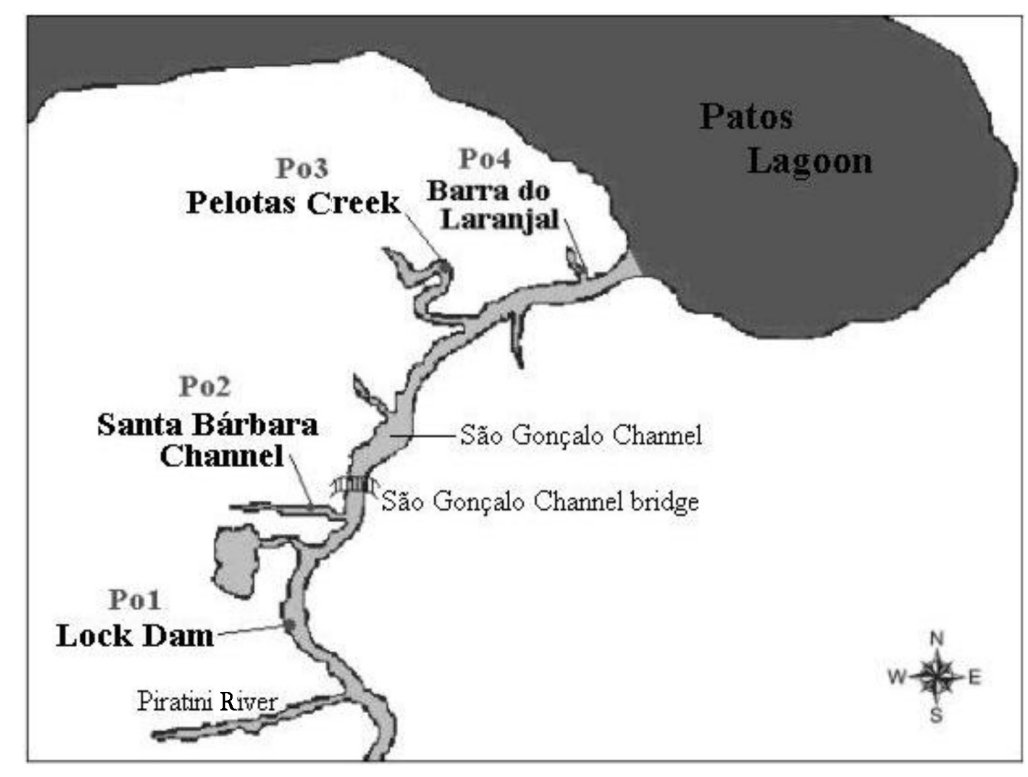

Figure 1. Map showing sampling stations along São Gonçalo Channel. Po1, 2, 3, 4 = Points 1, 2, 3, 4. Source: Environmental Chemistry Laboratory - UCPel. 


\section{Mutagenicity analysis}

For the A. cepa test, four onion bulbs (repetitions) were used for each point, all small and uniform in size, unsprouted and healthy, from the same origin, and using drinking water as a negative control. Bulbs were subjected to treatment solutions for $48 \mathrm{~h}$. Afterward, root endings were collected, fixed in Carnoy, and stored in $70 \%$ ethanol. For slide preparation, a $5 \mathrm{~N} \mathrm{HCl}$ hydrolysis was performed, followed by staining with acetic orcein.

Cell analysis was done using a regular light microscope, with a 40X objective lens. For each sampling point, 8000 cells were examined, 2000 of which by repetition, determining a) the number of cells in division (DC), b) MA: anaphasic bridges and fragments, chromosomes lost in anaphase, chromosomes delayed in metaphase and prophase, and other mitotic anomalies), c) IA: identifying cells with micronuclei, binucleated cells, linked nuclei, buds, and other anomalies, and d) TA: mitotic and interphase ones (Figure 2).
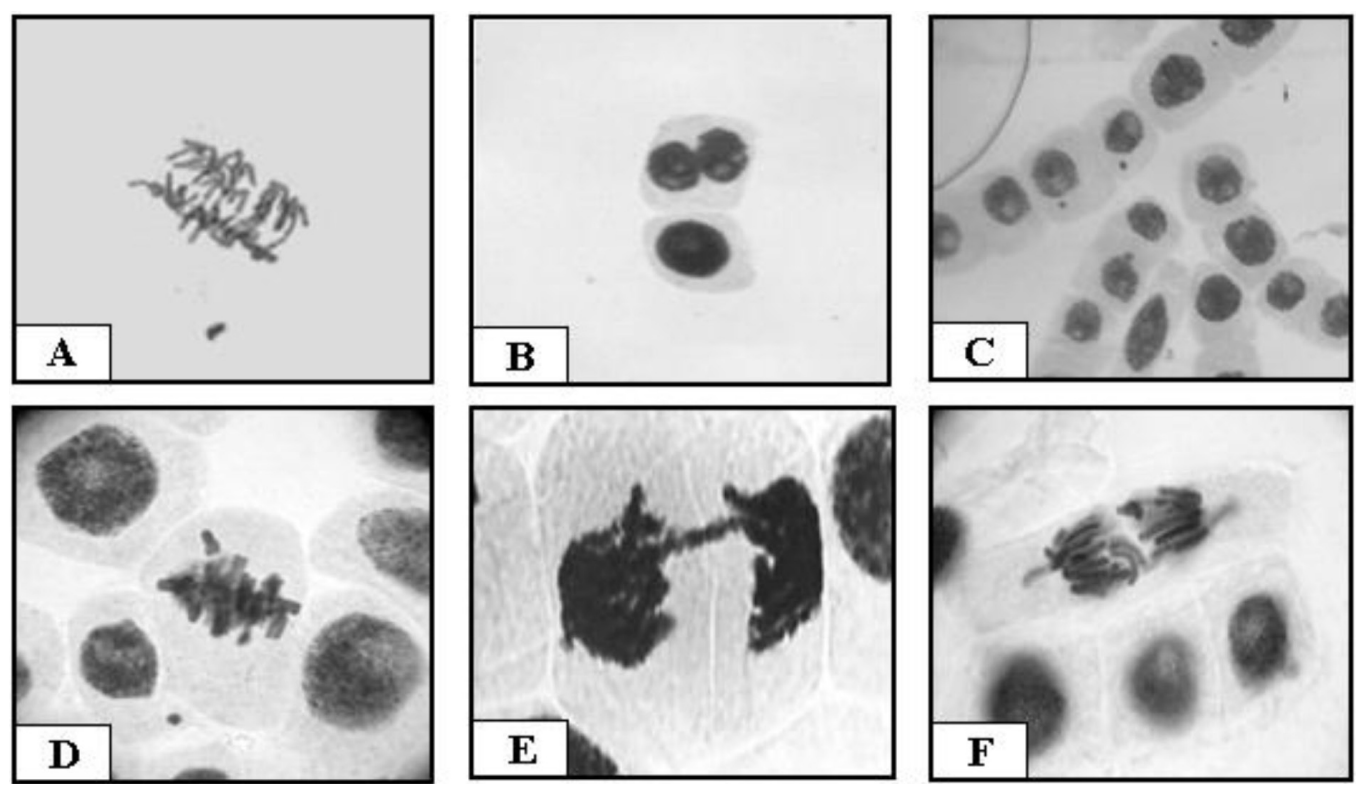

Figure 2. Cell changes found in Allium cepa. Multipolar anaphase (A), binucleated cell (B), cells with micronuclei (C), chromosome lost in metaphase (D), bridge in telophase (E), and anaphase with delay and lost chromosome (F). Source: Genetics Laboratory - UCPel.

\section{Physicochemical analysis}

For the physicochemical analysis of water, acidity $\left(\mathrm{mg} \mathrm{CaCO}_{3} / \mathrm{L}\right)$, alkalinity ( $\mathrm{mg}$ $\left.\mathrm{CaCO}_{3} / \mathrm{L}\right)$, chlorides $(\mathrm{mg} / \mathrm{L} \mathrm{Cl})$, hardness $\left(\mathrm{mg} \mathrm{CaCO}_{3} / \mathrm{L}\right), \mathrm{pH}$, and conductivity $(\mu \mathrm{S} / \mathrm{cm})$ were 
determined according to methods described in APHA (1998).

\section{Statistical analysis}

For the statistical analysis, a database was built with the statistics SPSS software, "for Windows", version 10.0, and differences were evaluated using the chi-square test and the Mann-Whitney U-test, with the level of significance set at $\mathrm{P} \leq 0.05$.

\section{RESULTS AND DISCUSSION}

Table 1 presents MA, IA, TA, DC, and MI data found in 2005 and 2007 for the channel. Statistical analysis results show that there was a significant increase in MA and TA between the years examined, suggesting an increment of toxic substances in the waters of São Gonçalo Channel in 2007. General channel data for the two years were also compared with control data, showing that for both 2005 and 2007 the same occurred, that is, the anomaly data found in the channel were significantly higher than those of control, with only MI remaining unchanged.

Table 1. Mitotic index, mean and standard deviation for mitotic anomalies, interphase anomalies, total anomalies, cells in division, and physicochemical analysis of São Gonçalo Channel, for years 2005 and 2007, Pelotas, RS.

\begin{tabular}{|c|c|c|c|c|c|c|c|}
\hline Variables & Channel 2005 & $P$ & Control & Channel 2007 & $\mathrm{P}$ & Control & $P(2005 \times 2007)$ \\
\hline MA & $1.60 \pm 1.51$ & 0.910 & $0.25 \pm 0.44$ & $13.68 \pm 7.27$ & 0.025 & $9.31 \pm 6.48$ & 0.0001 \\
\hline IA & $12.59 \pm 13.31$ & 0.004 & $129.00 \pm 37.95$ & $10.00 \pm 5.67$ & 0.023 & $109.81 \pm 50.81$ & 0.314 \\
\hline TA & $14.20 \pm 13.78$ & 0.004 & $3.00 \pm 1.89$ & $23.68 \pm 10.07$ & 0.004 & $6.43 \pm 3.36$ & 0.002 \\
\hline $\mathrm{DC}$ & $116.56 \pm 71.08$ & 0.392 & $3.25 \pm 1.80$ & $117.09 \pm 54.66$ & 0.504 & $15.75 \pm 7.33$ & 0.314 \\
\hline $\mathrm{MI} \%$ & 11.65 & & 12.90 & 5.84 & & 5.46 & \\
\hline Acidity & $48.05 \pm 40.34$ & & & $14.65 \pm 9.10$ & & & 0.0001 \\
\hline Alkalinity & $58.96 \pm 61.91$ & & & $59.80 \pm 18.46$ & & & 0.0001 \\
\hline Chlorides & $1752.87 \pm 4620.07$ & & & $68.65 \pm 13.63$ & & & 0.0001 \\
\hline Hardness & $1482.92 \pm 3669.94$ & & & $120.56 \pm 307.49$ & & & 0.0001 \\
\hline $\mathrm{pH}$ & $6.51 \pm 0.49$ & & & $7.06 \pm 0.77$ & & & 0.0001 \\
\hline Conductivity & $10881.87 \pm 28478.12$ & & & $135.03 \pm 223.86$ & & & 0.0001 \\
\hline
\end{tabular}

MA: mitotic anomalies; IA: interphase anomalies; TA: total anomalies; DC: cells in division; MI: mitotic index. Source: Genetics Laboratory - UCPel.

In regard to the physicochemical analysis for 2005, acidity, chloride, hardness, and conductivity levels showed values above those recommended by Brazilian government standards (Ministério da Saúde, 2004; CONAMA, 2005), and significantly different from those found in 2007, which could indicate impacted environments (CETESB, 1995).

In order to verify the occurrence of differences in the anomalies examined among the four seasons of the year (Table 2), the chi-square test was performed, showing no evidence of differences among seasons for both 2005 and 2007, though it is known that in the fall and winter the rainfall level is higher than in spring and summer, which would affect the levels of toxic substances. Comparing the data for each season with the control using the Mann-Whitney U-test, a significant increase was found for MA and TA in the summer. In the fall, winter and spring, there was a significant increase in IA and TA. Such finding indicates that the channel water had a mutagenic effect in all seasons of 2005. However, this effect was not found for 2007. 


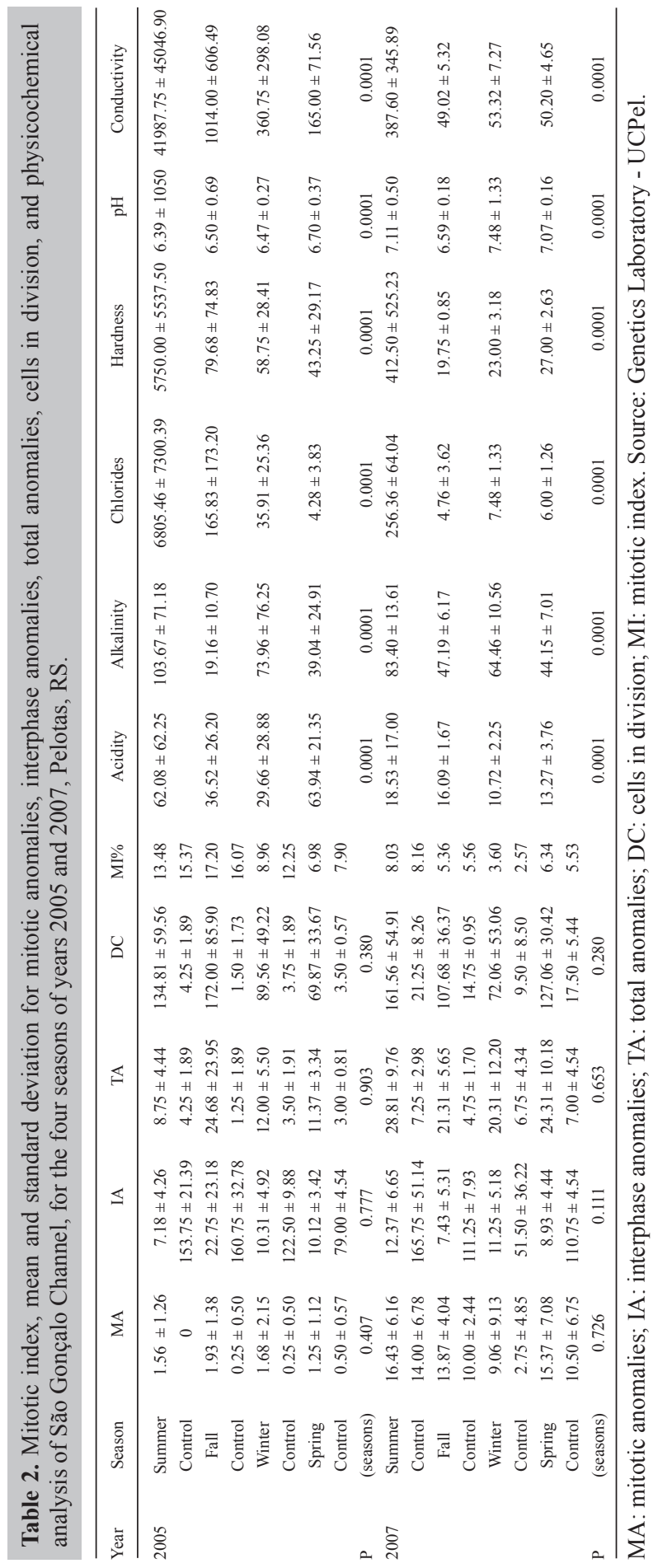


The physicochemical parameters for 2005 showed high values in the summer, in regard to chloride and hardness levels. Conductivity stood out in all seasons, and the variables acidity, alkalinity and $\mathrm{pH}$ were stable, though displaying significant differences. In 2007, acidity, which depends on $\mathrm{pH}$, was high in all seasons, whereas $\mathrm{pH}$ was in a normal range between 6 and 9 , as well as alkalinity, which ranged between 10 and $500 \mathrm{mg} \mathrm{CaCO} / \mathrm{L}$, chloride with indices below the maximum allowed $(250 \mathrm{mg} / \mathrm{L} \mathrm{Cl})$, and hardness also with values below the maximum allowed $\left(500 \mathrm{mg} \mathrm{CaCO}_{3} / \mathrm{L}\right)$. Conductivity was only high during the summer, with values above $100 \mu \mathrm{S} / \mathrm{cm}$ (CONAMA, 2005).

Tables 3 and 4 show data for the variables examined at four points along the channel for the four seasons of 2005 and 2007, respectively. It is seen that there was no change among the four points in any of the seasons in both years examined. Each sampled point was also compared with regard to the different seasons. All points showed the same behavior in the different seasons, in both 2005 and 2007.

In Table 3, relative to 2005, data from each point were also compared to those from the control for all seasons (Mann-Whitney U-test). Point 1 showed more IA and TA than the control in all seasons. This point is located near the Lock Dam, which was chosen in order to control the input of salt water into the northern portion of Mirim Lagoon. The fact that it demonstrated more anomalies could be explained by the salinization, which is more frequent during the summer. Still, the anomalies showed an increase in all seasons, so that there must be another polluting factor altering water quality. As there are farming fields surrounding this point, and considering the natural leaching process, the chemical products used by the farmers may reach the channel. As the waters are blocked by the dam, an accumulation of such substances is possible at this location.

Point 2, which corresponds to the mouth of Santa Bárbara Channel, showed more anomalies in the fall (MA, IA, TA), winter (IA, TA, DC), and spring (MA, IA, TA). Such finding is likely to be due to the high load of domestic effluents dumped into the channel. In all seasons of that year, Pelotas Creek (Point 3 ) showed significant differences in the anomalies examined relative to the control. This could be explained by the fact that this place also receives a high load of effluents from housing projects located along the bank. Such finding is corroborated by research conducted at UCPel's Genetics Laboratory, which has used aquatic macrophytes from the low Pelotas Creek to assess effluent impacts, also indicating the incidence of anomalies (Santos et al., 2005).

Point 4, located in Barra do Laranjal near the mouth of the channel into Patos Lagoon, did not show anomalies only in the winter relative to the control, probably due to the high rainfall level during the season.

In regard to 2007 (Table 4), data from each sampling point were compared to the control for each season (Mann-Whitney U-test). It was found that, during the summer, winter and spring, Point 1 showed data similar to those of the control. Only in the fall were there significant differences regarding MA, TA, and DC. Such findings may be due to high temperatures, which were frequent, and the low rainfall level during the fall season. Point 2 was homogeneous and similar to the control in all seasons, and Point 3 showed more IA than the control in winter. Such finding was probably due to the great amount of rain, which dilutes the toxic substances in the water. Point 4 only showed a decrease in cell division in the winter, but the number of anomalies increased in the fall and summer. In the spring, its behavior was homogeneous. 


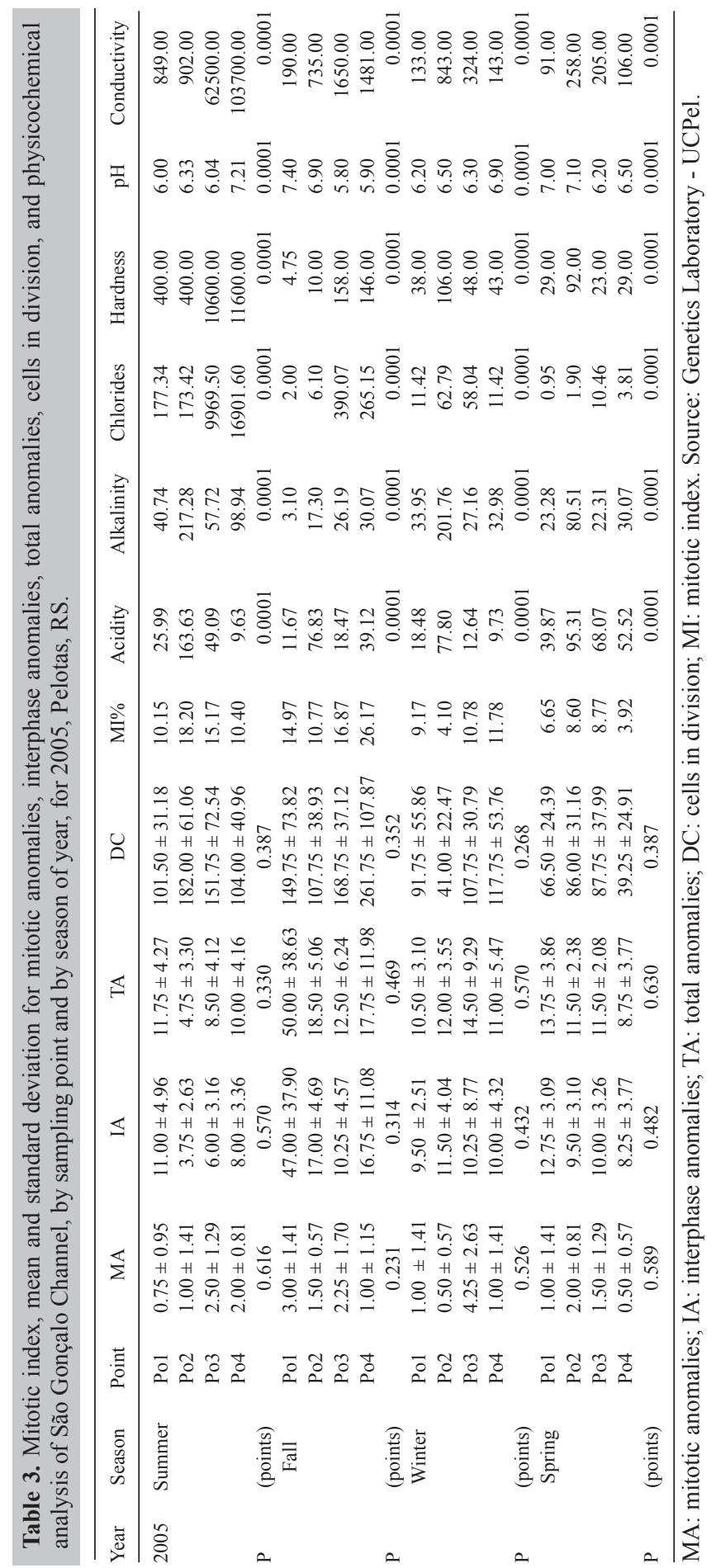




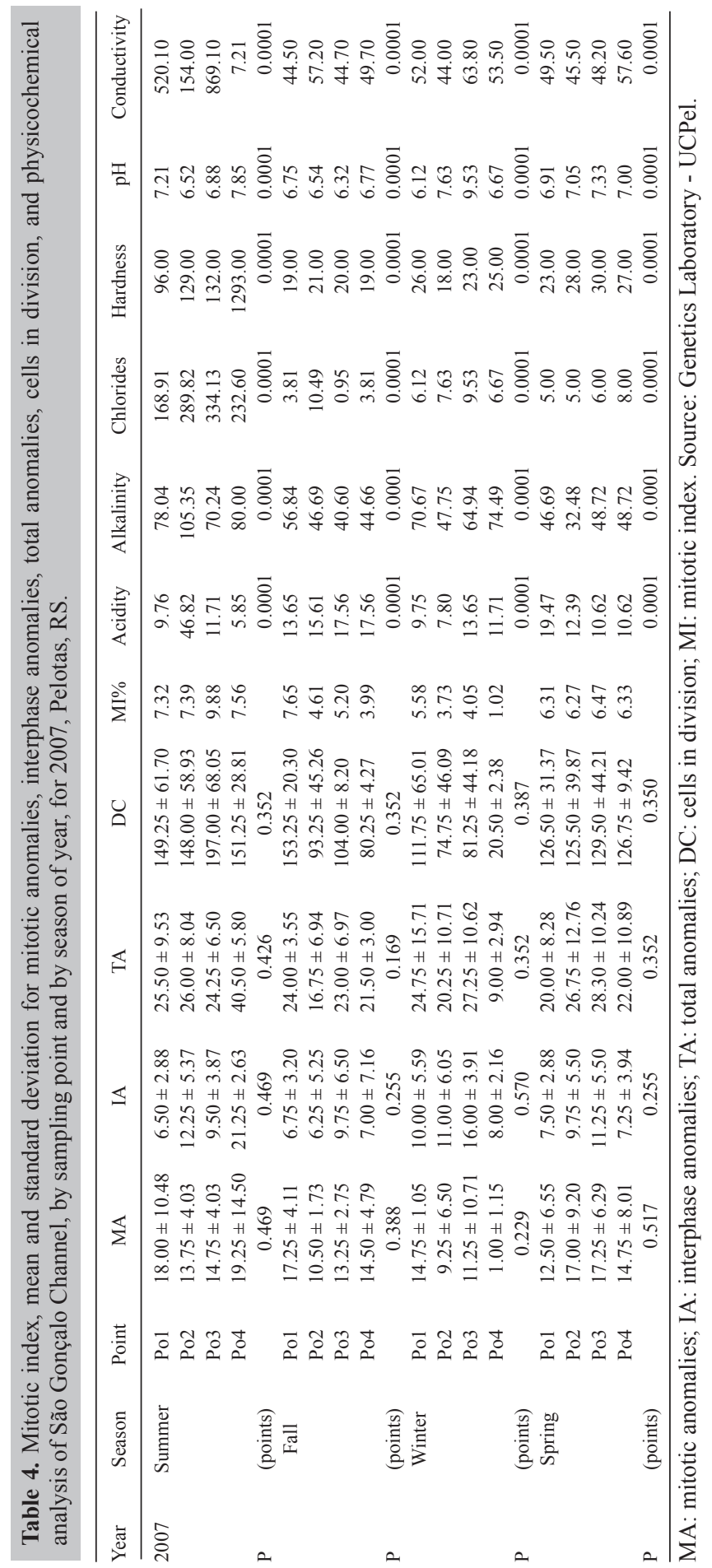


The physical and chemical determinations presented in Tables 3 and 4 show that, in regard to 2005 and 2007, respectively, all variables examined showed significant differences in the four channel points for all seasons. In the year 2005, Point 4 (Barra do Laranjal) was the one displaying more parameters exceeding the Brazilian water-body quality standards (CONAMA, 2005) and the drinkability standards defined by the Brazilian Health Ministry (Portaria No. 518, Ministério da Saúde, 2004). In 2007, Point 3 (Pelotas Creek) stood out the most. In regard to the seasons, summer was distinguished in both years studied.

From the results obtained through the seasonal assessment of São Gonçalo Channel waters in the years 2005 and 2007, it may be seen that there are considerable mutagenicity levels in the channel, and that such mutagenic potential showed an increase in 2007. Such increase is likely to be due to an increment in toxic substances dumped into its course, as the channel receives effluents from several anthropic activities, besides being the receiving body for several other small water courses. Therefore, this study serves as a warning for the population that lives by the channel's banks and for those who use its water for a given purpose, reminding that São Gonçalo Channel makes the connection between Mirim Lagoon and Patos Lagoon, environments of inestimable biological importance, thus justifying the need for its monitoring and preservation.

\section{ACKNOWLEDGMENTS}

The authors would like to thank their colleagues and the technician Ana Elisa Bender from the Genetics Laboratory of the Health School, and colleagues from the Environmental Chemistry Laboratory of the Environmental Sciences School, as well as the workers from Universidade Católica de Pelotas, who helped with transportation during samplings.

\section{REFERENCES}

Alba-Tercedor J (1994). El Entomólogo y los Problemas de Degradación de los Sistemas Acuáticos. In: Environmental Management and Arthropod Conservation (Jiménez-Peydró R and Marcos-García MA, eds.). Asociación Española de Entomologia, Valencia, 131-138.

American Public Health Association (APHA) (1998). American Water Work Association (AWWA) and Water Polution Control Federation (WPCF). Standard Methods of the Examination of Water and Wastewater. 19th edn. New York.

Capitoli RR and Bemvenuti CE (2005). Cenários de Distribuição e Processo de Colonização do Mexilhão Dourado Limnoperna fortunei (Dunker 1857) entre as Bacias da Lagoa dos Patos e Lagoa Mirim (RS - Brasil). Available at [http://www.mma.gov.br/port/sbf/invasoras/capa/docs/paineis/cenarios_distribuicao.pdf]. Accessed July 15, 2007.

Companhia de Tecnologia de Saneamento Ambiental (CETESB) (1995). Variáveis de qualidade das águas. Secretaria de Estado do Meio Ambiente. Available at [http://www.cetesb.sp.gov.br/default.asp]. Accessed October 20, 2007.

Conselho Nacional do Meio Ambiente (CONAMA) (2005). In: Resolução № 357 de Março de 2005. Ministério do Meio Ambiente, Diário Oficial da União, Brasil. Available at [http://www.mma.gov.br/port/conama/res/res05/res35705. pdf]. Accessed September 12, 2007.

Evandri MG, Tucci P and Bolle P (2000). Toxicological evaluation of commercial mineral water bottled in polyethylene terephthalate: a cytogenetic approach with Allium cepa. Food Addit. Contam. 17: 1037-1045.

Ferreira A and Cunha C (2005). Environmental sustainability of water resources in the city of Rio de Janeiro, Brazil. Rev. Panam. Salud Publica 18: 93-99.

Fiskejö G (1993). The Allium Test - A Potencial Standard for the Assessment of Environmental Toxicity. In: Environmental Toxicology and Risk Assessment. Vol. 2. ASTM STP 1216. (Gorsuch JW, Dwyer FJ, Ingersoll CG and La Point TW, eds.). American Society for Testing and Materials, Philadelphia, 331-345.

McMichael AJ (2000). The urban environment and health in a world of increasing globalization: issues for developing countries. Bull. World Health Organ. 78: 1117-1126. 
Ministério da Saúde (2004). Portaria No 518, de 25 de Março de 2004. Diário Oficial da União, Brasil. Available at [http:// dtr2004.saude.gov.br/dab/saudebucal/legislacao/portaria518_25_03_04.pdf]. Accessed September 12, 2007.

Ministério dos Transportes (2001). Secretária de Transportes Aquaviários, Departamento de Hidrovias Interiores. Canal São Gonçalo. Available at [http://www.transportes.gov.br/bit/hidro/gcanalsaogoncalo.htm]. Accessed November 12, 2007.

Moraes DS and Jordão BQ (2002). Water resources deterioration and its impact on human health. Rev. Saude Publica 36: 370-374.

Moraes DSL, Jordão BQ, Oliveira MD and Eilers V (2002). Investigação da Atividade Mutagênica de Efluente Municipal pelo Teste de Allium. CD Rom. In: $48^{\circ}$ Congresso Nacional de Genética Sociedade Brasileira de Genética (SBG), Águas de Lindóia.

Pereira DG, Carvalho S and Fonseca CA (2002). Avaliação da genotoxicidade em planta do cerrado. Biotecnol. Cienc. Desenvolv. 29: 128-133.

Santos TCO, Jorge PM, Oliveira GR, Ribeiro SG, et al. (2005). Biomonitoramento das Águas do Baixo Curso do Arroio Pelotas. In: III Congresso Sul-Riograndense de Biociências, Pelotas - RS. Anais do III Congresso Sul-Riograndense de Biociências, Pelotas, 17.

Smaka-Kincl V, Stegnar P, Lovka M and Toman MJ (1996). The evaluation of waste, surface and ground water quality using the Allium test procedure. Mutat. Res. 368: 171-179. 